Šefika Alibabić1,

Emir Avadgić2

\title{
RAZVOJNI ELEMENTI U STRATEGIJAMA OBRAZOVANJA ODRASLIH ${ }^{3}$
}

\section{- Sažetak -}

Jedan od osnovnih $i$ dominantnih puteva realizovanja doživotnog obrazovanja i učenja je obrazovanje odraslih. Za uspešnost toga procesa neophodno je adekvatno okruženje, stoga je zadatak svake vlade i socijalnih partnera da osiguraju okruženje koje podržava stalno i kontinuirano sticanje novih znanja i veština. Obrazovanje odraslih je područje koje je u poslednje vreme u većini zemalja Jugoistočne Evrope, usled brojnih tranzicijskih problema, presvih ekonomskih, dospelo na margine državne brige. Iako postaje sve važnije polje interesovanja obrazovnih politika u regiji, obrazovanje odraslih još uvek nije prioritet. Neke zemlje Jugoistočne Evrope imaju usvojene strategije obrazovanja odraslih $i$ zakone o obrazovanju odraslih, međutim njihovo usvajanje ne znači uvek i implementaciju odnosno „točak” koji će pokrenuti razvoj obrazovanja odraslih i ostvarivanje obrazovnih ciljeva. S obzirom da je svrha državne strategije obarzovanja odraslih obezbeđivanje planskog razvoja te delatnosti - planska izgradnja društvenog ambijenta $i$ relevantnih mehanizama $i$ resursa za obrazovanje $i$ učenje odraslih, odnosno kreiranje sistema za ostvarivanje misije $i$ za dosezanje vizije obrazovanja odraslih, neophodno bi bilo da strategije kao instrumenti obrazovne politike sadrže ključne razvojne elemente. Stoga je namera ovog rada da na osnovama kritičke analize četiri strategije zemalja regiona, sagleda $i$ utvrdi zastupljenost ključnih razvojnih elemenata u usvojenim strategijama. Zastupljenost je merena skalom procene, pri čemu je osnovu

1 Prof. dr. Šefika Alibabić, Filozofski fakultet, Beograd.

2 Emir Avdagić, M.A, dvv international u Bosni i Hercegovini.

3 Tekst je preuzet iz časopisa Pedagogija 1/2012 - Beograd, a nastao je u okviru projekta „Modeli procenjivanja i strategije unapređivanja kvaliteta obrazovanja" (179060), koji se realizuje na Institutu za pedagogiju i andragogiju Filozofskog fakulteta u Beogradu, a koji finansira Ministarstvo prosvete i nauke Republike Srbije. 
procene činio kritički sud istraživača prilikom analize strategija. Analiza je rezultirala zaključkom da zakon o obrazovanju odraslih $i$ finansiranje obrazovanja odraslih kao razvojni elementi uglavnom spadaju u kategoriju „veoma naglašenih razvojnih elemenata”, dok se kadrovi za obrazovanje odraslih tretiraju kao razvojni element koji je neadekvatno naglašen (sa prosekom 1,75) u analiziranim strategijama.

Zakon, finansiranje, institucije, kadrovi kao razvojni elementi su u našem istraživanju posmatrani pojedinačno - izolovano, iako njihova razvojna snaga dolazi do izražaja tek u njihovom združenom delovanju. U tom kontekstu, a na osnovu rezultata analize, može se zaključiti da svaka analizirana strategija odražava snažan razvojni potencijal izražen kroz združeno delovanje razvojnih elemenata.

\section{Ključne riječi: doživotno obrazovanje i učenje, obrazovanje odraslih, strategija obrazovanja odraslih, razvojni elementi strategije, obrazovne politike.}

\section{Uvod}

Rezultatima Kopenhaškog i Bolonjskog procesa doživotno učenje se proširilo i van područja obrazovanja odraslih (za koje se uglavnom vezivalo) i jasnije povezalo sve obrazovne nivoe. Obrazovanje odraslih je glavni nosilac ili pak put realizacije doživotnog učenja koje dobija sve više na važnosti, ne samo kao ideja, već kao filozofsko izvorište politike obrazovanja. Često je termin doživotno učenje upotrebljavan kao sinonim za obrazovanje odraslih, iako između tih termina postoje jasne razlike. Dok se doživotnim učenjem obuhvata i usklađuje obrazovanje i vaspitanje dece, mladih i odraslih, „obrazovanjem odraslih se usklađuju samo oblici formalnog, neformalnog i informalnog obrazovanja i učenja odraslih i to po načelu horizontalnog povezivanja" (Bečić i dr. 2009: 70). U pojmovnoj ravni nauka o obrazovanju, naročito andragoške nauke, mogu se uočiti brojni pojmovi bliski pojmu obrazovanje odraslih, bilo da su integrisani unutar njega (kao npr. dalje i kontinuirano obrazovanje), ili da su mu nadređeni i obuhvataju ga kao što je pojam doživotno obrazovanje i učenje. Osnovna odrednica za definisanje obrazovanja odraslih je starosna granica, te se tako pod obrazovanjem odraslih podrazumeva obrazovanje osobe starije od osamnaest godina, bez obzira na vrstu, sadržaj, nivo obrazovanja ili način sticanja obrazovanja. Prema tome, obrazovanje odraslih je manifestacija doživotnog obrazovanja i učenja i stoga deo globalnog obrazovnog sistema. Ono je faktor ekonomskog razvoja 
(povećanja produktivnosti i konkurentnosti privrede i zapošljavanja); način brzog reagovanja na potrebe privrede i tržišta rada izazvane promenama; način da se podrži lični razvoj i mogućnost pojedinca da bude zaposlen i nezavisan, a uz to i zadovoljan poslom, zdrav i aktivan (Alibabić, 2011). Sve su to argumenti u prilog tezi da obrazovne politike koje zapostave obrazovanje odraslih kao manifestni oblik ili put doživotnog obrazovanja i učenja, daleko su od razvojnih društvenih politika, daleko su od politika koje stvaraju uslove za uspešnost koncepata društva znanja i doživotnog učenja i obrazovanja.

U obrazovnim politikama zemalja Evropske Unije (EU)je već duže vremena dominantan pristup koji polazi od društva koje se temelji na znanju, jer jedino što je izvesno jeste to da znanje postaje najvažniji razvojni i privredni resurs (Boud and Garrick, 1999). Znanje treba da bude ključni faktor koji može da odgovori na globalne ekonomske pretnje, te da omogući stabilan i održiv razvoj svakog društva (Savićević, 2000). Ovo nije moguće ako tom cilju ne stremi obrazovna politika zasnovana na konceptu ili filozofiji doživotnog obrazovanja i učenja, politika koja omogućava i obezbeđuje obrazovne tokove (uvek i za sve uzrasne kategorije), a potom i njima upravlja. „Koncepcija sadrži obrazovne ciljeve, strategija puteve njihove realizacije, sistem sadrži institucije, oblike i načine ostvarivanja obrazovnih ciljeva, a politika za sve to svesno stvara uslove, artikuliše ih i njima upravlja"(Alibabić, 2002: 79). Imajući u vidu da postoje velike razlike između obrazovnih politika koje susrećemo u zemljama EU i obrazovnih politika zemalja Jugoistočne Evrope, interesantno je sagledati da li i u kojoj meri obrazovne politike u Jugoistočnoj Evropi pridaju važnost obrazovanju odraslih donošenjem i usvajanjem strategija za obrazovanje odraslih kao delova svojih politika. Saglasni sa činjenicom da strategija za obrazovanje odraslih treba da sadrži planove ili planirane puteve realizacije obrazovnih ciljeva zanimalo nas je: da li i u kojoj meri su u strategijama za obrazovanje odraslih u zemljama Jugoistočne Evrope zastupljeni razvojni elementi neophodni za ostvarivanje strateških planova, odnosno za razvoj obrazovanja odraslih - za realizaciju obrazovnih ciljeva?

Širi kontekst obrazovanja odraslih u Jugoistočnoj Evropi se značajno razlikuje od onog u razvijenim zemljama iz više razloga. Sagledamo li to detaljnije ustanovićemo da predstavljanje obrazovanja odraslih na političkoj ravni i približavanje postignućima Zapadne Evrope nije na istom nivou u zemljama Jugoistočne Evrope, iako su većina tih zemalja imale dugu i uspešnu zajedničku tradiciju na području obrazovanja odraslih. Iz tih razloga smo se opredelili analizirati strategije za obrazovanje odraslih četiri zemlje regije i 
sagledati da li i u kojoj meri te strategije sadrže/apostrofiraju elemente koji podstiču razvoj obrazovanja odraslih i omogućavaju ga. Na osnovu izveštaja, deklaracija i rezolucija međunarodnih konferencija o obrazovanju odraslih i rasprava o razvojnosti obrazovanja u dostupnoj nam literaturi, izdvojili smo četiri ključna elementa koji pouzdano mogu doprineti razvoju obrazovanja odraslih, te se stoga mogu označiti razvojnim elementima strategije neophodnim za ostvarenje obrazovnih ciljeva. To su sledeći elementi:

- zakon o obrazovanju odraslih,

- institucije/provajderi - realizatori obrazovanja odraslih,

- kadrovi za obrazovanje odraslih i

- finansiranje obrazovanja odraslih.

Gotovo da je i bez objašnjenja očito da navedeni elementi, ako su jasno određeni i ,uređeni” obezbeđuju i osiguravaju razvoj delatnosti obrazovanja odraslih, odnosno podržavaju i omogućavaju misiju te delatnosti i „vode” ka njenoj viziji. I pored toga, dajemo kratko objašnjenje naše odluke o izboru razvojnih elemenata. Zašto zakon - zato što unosi red u obrazovnu delatnost i čini je sistemom, a razvoj je moguć samo kroz sistem, nikako kroz njegovu suprotnost koju imenujemo haosom. Institucionalno-organizaciona i realizatorska mreža kojom je obuhvaćeno i vrlo važno socijalno partnerstvo, čini objektivni temelj sistema, dok kadrovski potencijal - kompetentnost kadrova kao prvi uslov kvaliteta obrazovne delatnosti i obrazovnog procesa, predstavlja subjektivni temelj sistema obrazovanja odraslih. Zašto finansiranje - jer ukazuje na brigu svih aktera (države, socijalnih partnera, pojedinaca) za obrazovanje odraslih, a time i na značaj obrazovanja odraslih u razvojnim projekcijama društva.

Strategije za obrazovanje odraslih koje su bile predmet naše analize su strategije Republike Crne Gore, Republike Hrvatske, Republike Makedonije i Republike Srbije. Iako je obrazovanje odraslih u Bosni i Hercegovini spomenuto u „Strategiji za razvoj stručnog obrazovanja” (2007) i „Strateškim pravcima za razvoj obrazovanja u Bosni i Hercegovini sa planom implementiranja 2008.-2015.” (2008), Bosna i Hercegovina neće biti predmet naše analize, jer nema usvojenu strategiju za obrazovanje odraslih ni na entitetskim nivoima, a ni na državnom nivou, iako je jedan entitet - Republika Srpska, usvojio Zakon o obrazovanju odraslih u junu 2009. godine. Pored toga, $\mathrm{BiH}$ je izostavljena i zbog kompleksnosti samog administrativnog uređenja i samim time više obrazovnih politika u zemlji. Po Dejtonskom mirovnom sporazumu obrazovanjem se upravlja na nivou entiteta, kantona i Distrikta 
Brčko, tako da u zemlji postoji 13 politika obrazovanja, koje na državnom nivou sa ograničenim ovlastima koordinira Ministarstvo civilnih poslova Bosne i Hercegovine (Nacionalni izvještaj o razvoju i stanju obrazovanja i učenja odraslih-BiH, 2008).

\section{Terminološko konceptualno razmatranje}

Iako se termin strategija u vojnom smislu koristi već dugo vremena, on je u obrazovnom kontekstu pojam novijeg datuma. Pojam strategija se sporadično javljao u naučnim i stručnim časopisima šezdesetih godina XX stoljeća, ali je tek osamdesetih godina istog stoljeća postao jedan od centralnih pojmova modernog menadžmenta. Danas se pojam strategija koristi za jednu sveobuhvatnu nameru koja je orijentisana ka ostvarivanju ciljeva, za dugoročan plan koji se realizuje primenom kratkoročnih taktika (kao delova jedne strategije). Strategija treba da postavi „težište” i pokaže na koji način - kako da se ostvari željena misija, uz pomoć taktike kao instrumenta operacionalizacije strateških namera i ciljeva. Za Mintzberga „strategija je jedna od onih riječi, koju rado definiramo na jedan, ali ipak upotrebljavamo na sasvim drugi način". ${ }^{4} \mathrm{Na}$ osnovu Mintzbergovog određenja vidljivo je da se o pojmu strategije može govoriti samo generalno i da detaljnija definicija samog pojma zavisi od specifične situacije odnosno polja delovanja same strategije. Pod strategijom se može podrazumevati saznanje gde smo, gde želimo biti i kako tamo stići. Strategiju obrazovanja odraslih bismo mogli označiti kao dugoročan plan za realizaciju koncepcije (ciljeva) obrazovananja odraslih. Svrha strategije obrazovanja odraslih je planska izgradnja društvenog ambijenta i relevantnih mehanizama i resursa za obrazovanje i učenje odraslih, kreiranje sistema za ostvarivanje misije i za dosezanje vizije obrazovanja odraslih. Veliki doprinos razvoju nacionalnih strategija za obrazovanje odraslih zasigurno je dao i UNESCO svojim konferencijama (1949. u Elsionoreu; 1960. u Montrealu; 1972. u Tokiju; 1985. u Parizu,ž; 1997. u Hamburgu i 2009. u Belemu) na kojima se oblikovala osnovna koncepcija obrazovanja odraslih, te prihvaćene strategije razvoja međunarodnih dimenzija, a time i pokrenute inicijative za praktične akcije i razvoje samih strategija na nižim nivoima. Reformi na polju obrazovanja odraslih kao i samom razvoju sistema obrazovanja odraslih u Jugoistočnoj Evropi, doprinele su zasigurno i dve deklaracije potpisane od strane ministara obrazovanja Jugoistočne Evrope i to 2003. godine u Skoplju i 2006. godine u Sarajevu u sklopu međunarodnih

4 Vidi http://www.strategienet.de/wasist.html, Stanje 18.01.2012. 
konferencija „Cijeloživotno učenje, obrazovanje odraslih i usavršavanje” i „Cijeloživotno učenje i obrazovanje odraslih - ključni faktor za ekonomsku i socijalnu obnovu Jugoistočne Evrope". U sarajevskoj deklaraciji su jasno istaknuta tri prioriteta $i$ to:

- razvoj strategija za obrazovanje odraslih,

- osiguranje i razvoj kvaliteta sektora za obrazovanje odraslih,

- zakonski okvir koji će pružiti garancije za raznoliku ponudu, uključujući i finansiranje obrazovanja odraslih, te razvoj institucionalne infrastrukture organizacija za obrazovanje odraslih. ${ }^{5}$

\section{Strategije obrazovanja odraslih u Jugoistočnoj Evropi}

Ideja doživotnog učenja nije tekovina našeg doba, njene korene treba tražiti mnogo pre objavljivanja knjige E. Faure-a „Learning to be” iz 1972.godine. Sa svojim delom „The Inquiring Mind” i tvrdnjom da koreni doživotnog učenja leže u drevnom judaizmu, Houl se može smatrati ocem doživotnog učenja u modernom smislu (Knoll, 2011:7-21). Međutim, doživotno obrazovanje i učenje se danas više nego ikad ranije smatra „opštim dobrom”, koje nije na nivou ideje, već na nivou svakodnevne prakse i svakodnevnog života. Brojni su profesionalni izazovi našeg doba, a među univerzalne se mogu svrstati akceleracija promena, globalizacija poslovanja, rast konkurencije, nove tehnologije, nestabilnost i zahtevnost tržišta, revolucija znanja... Gde tražiti odgovore na navedene izazove, ako ne u doživotnom obrazovanju i učenju, u kontinuiranom razvijanju kompetentnosti zaposlenih (Alibabić, Milićević, Drakulić, 2011:71). Jedan od osnovnih i dominantnih puteva realizacije doživotnog obrazovanja i učenja je obrazovanje odraslih, proces kroz koji se zadovoljavaju obrazovne potrebe odraslih, potrebe za ličnim razvojem, kao i potrebe za kontinuiranim profesionalnim razvojem i aktualizacijom znanja i veština u skladu sa zahtevima tržišta rada. Za uspešnost toga procesa neophodno je adekvatno okruženje, stoga je zadatak svake vlade i socijalnih partnera da osiguraju okruženje koje podržava stalno i kontinuirano sticanje novih znanja i veština. Obrazovanje odraslih je područje koje je u poslednje vreme u većini zemalja Jugoistočne Evrope, usled brojnih tranzicijskih problema, pre svih ekonomskih, dospelo na margine državne brige. Iako postaje sve važnije polje interesovanja obrazovnih politika u regiji, obrazovanje odraslih još uvek nije prioritet u zemljama Jugoistočne Evrope. Neke zemlje u regionu imaju usvojene strategije obrazovanja odraslih i zakone o obrazovanju odraslih,

5 Vidi „Obrazovanje odraslih” - Časopis za obrazovanje odraslih i kulturu, BiH, Broj 2/2006, str. 39. 
međutim njihovo usvajanje ne znači uvek i implementaciju odnosno „točak” koji će pokrenuti razvoj obrazovanja odraslih i ostvarivanje obrazovnih ciljeva (Tabela 1.).

\section{Tabela 1.: Strategije i zakoni o obrazovanju odraslih} u zemljama Jugoistočne Evrope

\begin{tabular}{|c|c|c|}
\hline Država & $\begin{array}{l}\text { Strategija obrazovanja } \\
\text { odraslih }\end{array}$ & $\begin{array}{l}\text { Zakon o obrazovanju } \\
\text { odraslih }\end{array}$ \\
\hline Albanija & --- & --- \\
\hline Bugarska & $\begin{array}{l}\text { Srednjoročna strategija } \\
\text { doživotnog učenja } \\
\text { usvojena 2008. godine }\end{array}$ & --- \\
\hline Bosna i Hercegovina & --- & $\begin{array}{l}\text { Zakon o obrazovanju } \\
\text { odraslih usvojen samo u } \\
\text { entitetu Republika Srpska } \\
\text { (2009) }\end{array}$ \\
\hline Republika Crna Gora & $\begin{array}{l}\text { Strategija obrazovanja } \\
\text { odraslih usvojena } 2006 . \\
\text { godine }\end{array}$ & $\begin{array}{l}\text { Zakon o obrazovanju } \\
\text { odraslih usvojen } 2002 \text {. } \\
\text { godine } \\
\text { Novi zakon o obrazovanju } \\
\text { odraslih usvojen } 2011 \text {. } \\
\text { godine }\end{array}$ \\
\hline Republika Hrvatska & $\begin{array}{l}\text { Strategija obrazovanja } \\
\text { odraslih usvojena } 2004 . \\
\text { godine }\end{array}$ & $\begin{array}{l}\text { Zakon o obrazovanju } \\
\text { odraslih usvojen } 2007 . \\
\text { godine }\end{array}$ \\
\hline Republika Makedonija & $\begin{array}{l}\text { Strategija obrazovanja } \\
\text { odraslih usvojena } 2010 . \\
\text { godine }\end{array}$ & $\begin{array}{l}\text { Zakon o obrazovanju } \\
\text { odraslih usvojen } 2008 \text {. } \\
\text { godine }\end{array}$ \\
\hline Republika Srbija & $\begin{array}{l}\text { Strategija obrazovanja } \\
\text { odraslih usvojena } 2006 . \\
\text { godine }\end{array}$ & --- \\
\hline Rumunija & --- & --- \\
\hline
\end{tabular}


Iznenađuje činjenica da Bugarska i Rumunija kao zemlje članice Evropske Unije ne slede politiku Unije i primer ostalih zemalja članica u kojima je obrazovanje odraslih u potpunosti ravnopravno kako sa predškolskim i školskim tako i sa visokim obrazovanjem i gde postoje razvijene kako strategije obrazovanja odraslih tako i zakonske osnove za ovo veoma važno područje. Iako je zahvaljujući internacionalnim projektima u Jugoistočnoj Evropi stvoreno okruženje puno entuzijazma, te su pokrenuti mnogi projekti za razmenu iskustava i razvoj ovog područja, rezultati ipak nisu zadovoljavajući. Trenutno se u regiji oseti neka vrsta usporavajućeg procesa te opadanja napora nadležnih kada je u pitanju razvoj sistema obrazovanja odraslih. To može biti posledica ozbiljnih, pa i političkih problema sa kojima se susreću zemlje u tranziciji, posebno zemlje u Jugoistočnoj Evropi, gde su politička previranja iz devedesetih godina prošlog stoljeća bila uzrok promena u svim životnim sferama. Potrebno je razviti nove mehanizme za usklađivanje oblasti obrazovanja odraslih sa zahtevima nove političke i ekonomske stvarnosti u regiji, a ti mehanizmi mogu biti promatrani kao razvojni elementi strategija obrazovanja odraslih te ćemo ih, kako smo u uvodu naveli, razmotriti na primerima četiri strategije iz zemalja našeg regiona. Zemlje za koje smo se opredelili su razvile vlastite strategije obrazovanja odraslih, za čiji nastanak su najzaslužniji predstavnici eksperata, ministarstava, udruženja poslodavaca, sindikata, privrednih komora i civilnog društva.

\section{Razvojni elementi strategija obrazovanja odraslih}

\section{Zakon o obrazovanju odraslih kao razvojni element strategije obrazovanja odraslih}

Strategija obrazovanja odraslih Republike Crne Gore (2006) ima cilj da razradi principe koje je postavio važeći Zakon o obrazovanju odraslih koji je u Crnoj Gori usvojen još 2002. godine. Iako je u vreme nastajanja i usvajanja Strategije postojao Zakon o obrazovanju odraslih, u samoj Strategiji je jasno vidljiva potreba za novom zakonskom i podzakonskom regulativom koja bi trebala da poboljša ambijent za implementaciju same Strategije. Jasno je vidljiva potreba za razvojem kapaciteta i kvaliteta sistema obrazovanja i obuke odraslih, te potreba za odgovarajućim finansijskim podsticajima i investicijama od strane države, poslodavaca, pojedinaca i drugih, što je neophodno obuhvatiti novim Zakonom. U Strategiji su jasno istaknute osnovne pretpostavke za uspešnu realizaciju same Strategije kao što je uspostavljanje održivog sistema obrazovanja odraslih što podrazumeva i odgovarajuću 
zakonsku regulativu. Preporučuje se usvajanje novog Zakona o obrazovanju odraslih koji će biti deo jedinstvenog sistema obrazovanja. U samoj Strategiji su vidljive i istaknute smernice za sadašnju politiku obrazovanja Crne Gore i za zakonski okvir, smernice koje su sadržane u mnogim drugim dokumentima, kao što su: Knjiga promjena, Agenda ekonomskih reformi za Crnu Goru, Strategija smanjenja siromaštva, Zakon o obrazovanju odraslih, Zakon o radu, Zakon o zapošljavanju, Zakon o državnim službenicima i namještenicima, Zakon o lokalnoj upravi i Zakon o finansiranju javne uprave (videti u: Strategija obrazovanja odraslih Crne Gore, 2006: 46). U međuvremenu, sigurno velikom zaslugom Strategije obrazovanja odraslih, došlo je do potrebe da se mnogi članovi Zakona izmene što nije bilo moguće amandmanima, pa je Republika Crna Gora 2011. godine usvojila novi Zakon o obrazovanju odraslih ${ }^{6}$. Pored ova dva važeća dokumenta (Strategije i Zakona) Crna Gora je usvojila i Plan obrazovanja odraslih za period 2010-2014. godine. Izrada Plana obrazovanja odraslih je obaveza iz Zakona o obrazovanju odraslih i izrađuje se za period od četiri godine. Nakon analize crnogorske Strategije može se zaključiti da je Zakon o obrazovanju odraslih implicitno, pa čak na momente i eksplicitno apostrofiran kao ,točak” razvoja ove delatnosti.

U Strategiji obrazovanja odraslih Republike Hrvatske (2004), Zakon se kao razvojni element Strategije posebno ističe u članu 4.1. Na putu prema evropskoj porodici «društva utemeljenog na znanju», u Strategiji je istaknuto da Republika Hrvatska prihvata doživotno učenje kao temelj svog celokupnog sistema obrazovanja, radi ostvarenja i unapređenja trajne zapošljivosti i aktivnog građanstva, te se u Strategiji kao jedan od ciljeva, kako bi bilo moguće ostvariti gore spomenuto, ističe potreba za stvaranjem zakonske i stručne pretpostavke, kako bi obrazovanje odraslih bilo jednako važan sastavni deo vaspitno-obrazovnog sistema Republike Hrvatske. Iz Strategije je vidljivo da je potreban poseban Zakon o obrazovanju odraslih, jer tada postojeći zakoni, koji delomično dotiču ovu oblast (Zakon o osnovnom školstvu, Zakon o srednjem školstvu, Zakon o pučkim otvorenim učilištima) ne uređuju u potpunosti oblast obrazovanja odraslih. Osim toga u Strategiji je istaknuto da se Republika Hrvatska prihvatanjem niza međunarodnih dokumenta obavezala na usvajanje Zakona o obrazovanju odraslih, na donošenje drugih mera i primenu političkih mehanizama za osiguranje prava na učenje svim odraslim osobama u saradnji sa svim partnerima. Republika Hrvatska je Zakon o obrazovanju odraslih usvojila tri godine nakon usvajanja Strategije - 2007. godine.

6 http://www.sllistcg.me/PravniAktDetalji.aspx?tag=\%7BB8328501-A894-4D51-8EA092B0B4B1CDC3\%7D, Stanje 25.01.2012. 
Strategija za obrazovanje odraslih (2010) u Republici Makedoniji usvojena je kasnije, u odnosu na druge zemlje regiona, mada se obrazovanje odraslih kao važan segment spominjalo i u „Nacionalnoj strategiji obrazovanja u Republici Makedoniji 2005-2015” iz 2006. godine. U tom dokumentu istaknuta je važnost donošenja Zakona za obrazovanje odraslih sa ciljem postojanja pravnog okvira za regulisanje obrazovanja odraslih u zemlji, jer je tadašnje stanje predstavljalo mnogo problema organizatorima obrazovanja odraslih koji zakonski nisu mogli regulisati svoj status i polje djelovanja (videti u: Nacionalna strategija obrazovanja u Republici Makedoniji 20052015, 2006:487). Zakon o obrazovanju odraslih usvojen je u januaru 2008. godine, a Strategija obrazovanja odraslih dve godine kasnije. Jedan od njenih ciljeva je bio da pokrene izradu pod-zakonskih akata i pravilnika, kako bi se stvorile stvarne pretpostavke za transformisanje obrazovanja odraslih u važan i sastavni element globalnog obrazovnog sistema u Republici Makedoniji, što je jasno naglašeno u Strategiji (Član 3). Strategija ističe važnost Zakona kao prvog dokumenta ove vrste koji reguliše sistem obrazovanja odraslih. Novina u Zakonu je bila i to što se pored formalnog obrazovanja prvi put i neformalno obrazovanje i učenje tretiraju kao značajan deo sveukupnog obrazovanja pojedinaca. Zahvaljujući Zakonu formiran je i Centar za obrazovanje odraslih Republike Makedonije kao javna ustanova, koja ima zadatak da usaglasi i integriše javne interese i interese socijalnih partnera za obrazovanje odraslih u Republici Makedoniji, te da unapredi sistem obrazovanja odraslih koji će omogućiti uključenost u kvalitetno obrazovanje tokom celog života i to za sve građanke i građane. Zakonom predviđeno osnivanje Centra za obrazovanje odraslih, koji je i zaživeo kao respektabilan faktor obrazovnog sistema, dobra je ilustracija Zakona kao razvojnog elementa Strategije.

Republika Srbija Strategiju obrazovanja odraslih vidi kao jedan od instrumenata za rešavanje ključnih socijalnih i ekonomskih problema (videti u: Strategija razvoja obrazovanja odraslih u Republici Srbiji, 2006:6). Kako bi kroz delatnost obrazovanja odraslih zemlja mogla da restrukturira i unapredi vlastiti ljudski potencijal, Strategija pored ostalog predviđa obezbeđenje kvaliteta obrazovanja i osposobljavanja odraslih kroz zakonsku regulativu. Strategija jasno definiše 4 cilja i unutar njih 14 zadatka. Zakon o obrazovanju odraslih kao jedan od razvojnih elemenata Strategije definisan je kao prvi zadatak četvrtog cilja pomoću kojeg bi trebala da se unapredi kvalitet obrazovanja i obuke odraslih. U Strategiji je istaknuto da je za razvoj i unapređenje obrazovanja odraslih nužno stvoriti adekvatan pravni okvir. Da bi se to ostvarilo Strategija predviđa donošenje posebnog Zakona kojim 
će se regulisati niz stvari neophodnih za funkcionisanje i razvoj delatnosti obrazovanja i obuke odraslih i to: delatnost institucija i organizacija za obrazovanje i obuku odraslih, institucionalni normativi i standardi, standardi obrazovanja i obuke, pitanja akreditacije i sertifikacije, finansijskog upravljanja, kao i druga pitanja od značaja za ovu oblast. Iako je Strategija obrazovanja odraslih usvojena još 2006. godine u kojoj je Zakon naglašen kao razvojni element Strategije, Zakon o obrazovanju odraslih u Republici Srbiji još nije prošao parlamentarnu proceduru i postao važeći dokument, iako njegov nacrt postoji već duže vreme.

\section{Institucije - realizatori obrazovanja odraslih kao razvojni element strategije obrazovanja Odraslih}

Strategija obrazovanja odraslih Republike Crne Gore se veoma opširno bavi problemom organizatora, institucija i provajdera obrazovanja odraslih te nudi jako detaljan prikaz stanja ovog elementa sistema i to u Aneksu 3 - Postojeća infrastruktura u obrazovanju odraslih i u Aneksu 5 Strategije - Pregled nosilaca aktivnosti u obrazovanju odraslih (videti u: Strategija obrazovanja odraslih Crne Gore 2005-2015, 2006). U Strategiji je istaknuto da pored postojanja pozitivne prakse u obrazovanju odraslih postoje mnogi problemi kada je u pitanju pružanje usluga obrazovanja i obuke za odrasle tj. kada je u pitanju institucionalna infrastruktura. U Strategiji se između ostalog navodi da se u narednom periodu mora povesti računa o povećanju broja opremljenih prostora koji odgovaraju procesu zadovoljavanja izraženih obrazovnih potreba kako pojedinaca, tako i privrede. Istaknut je i problem lošeg stanja nekih od postojećih institucija koje se bave obrazovanjem odraslih, te nepovoljan raspored kapaciteta u kojima se organizuje obrazovanje odraslih, posebno kada je riječ o populaciji koja živi u seoskim područjima. Akcent se stavlja i na prostorne kapacitete koji često nisu usklađeni sa zahtevima lica sa posebnim potrebama, a problemi su vidljivi i u smanjenju broja obrazovnih centara kod većih poslodavaca pa zbog toga treba težiti povećanju istih. Strategija ističe postojanje potrebe da se dalje razvijaju kapaciteti organizatora obrazovanja odraslih, shodno povećanom broju korisnika kojima će biti potrebne njihove usluge.

Strategija obrazovanja odraslih Republike Hrvatske u delu koji se odnosi na institucije odnosno realizatore obrazovanja odraslih daje samo jedan presek stanja odnosno trenutno stanje na tom polju (videti u: Strategija obrazovanja odraslih, 2004:20). U Strategiji nisu vidljivi predlozi rešenja ovog razvojnog elementa iako je posebno istaknuto, da pored toga što na 
prvi pogled obrazovna infrastruktura izgleda bogato i raznovrsno, ona u biti predstavlja jedan nekoherentan, voluntaristički sistem obrazovne infrastrukture te nejasan prostorni potencijal, nerešen finansijski sistem koji je često uslovljen ad hoc uticajima. U tu obrazovnu infrastrukturu spadaju prije svega: pučka otvorena učilišta, osnovne i srednje škole koje realiziraju programe obrazovanja odraslih, visoke škole, centri za obrazovanje u privrednim organizacijama, razne privatne škole, auto-škole, nevladine organizacije, udruženja poslodavaca, sindikati i mnogi drugi.

Strategija Republike Makedonije, pored ostalih, ima cilj i da doprinese saradnji institucija koje se bave formalnim i neformalnim obrazovanjem. $\mathrm{U}$ tom domenu Strategija ističe važnost saradnje vladinog sa nevladinim sektorom kao ključnim partnerom za razvoj obrazovanja odraslih. Da bi se taj cilj ostvario Strategija predviđa izgradnju mehanizama, te ostvarenje dinamične suradnje i podela odgovornosti i aktivnosti između Vlade i nevladinog sekotra. Član 6.7. Strategije se posebno bavi pitanjem institucija i organizacija kao razvojnim elementom same Strategije (videti u: Strategija za obrazovanje odraslih, 2010:15). Navedene su državne i javne institucije koje imaju nadležnost i odgovornost kada je obrazovanje odraslih u pitanju, a to su: Ministarstvo obrazovanja i nauke, Centar za obrazovanje odraslih, Savet za obrazovanje odraslih te Ministarstvo rada i socijalne politike. Jedinice lokalne samouprave i ostali socijalni partneri također imaju određene nadležnosti u ovoj oblasti. Pored toga, istaknuti su i mnogi realizatori obrazovanja odraslih (radnički univerziteti, centri za obuku, centri za strane jezike i informatičko obrazovanje, srednje škole, sindikati, komore, asocijacije i mnogi drugi). Jedan od ciljeva Strategije je i da se omogući razvoj postojećih institucija za obrazovanje odraslih, ali i da se podstakne i podrži formiranje novih, posebno u sredinama odnosno regijama koje imaju potrebu za ovim vidom institucija.

Institucionalizacija je kao razvojni element u Strategiji Republike Srbije ključno istaknuta kako bi se omogućila puna socijalna participacija, ohrabrila inicijativa, sistemski uvećala vrednost ljudskog kapitala te njegova puna uposlenost, produktivnost i efikasnost (videti u: Strategija razvoja obrazovanja odraslih u Republici Srbiji, 2006:10). Da bi se navedeno ostvarilo potrebno je omogućiti institucionalnu i programsku raznovrsnost, kako bi se stvaranjem široke mreže institucija i organizacija za obrazovanje odraslih proširile realne mogućnosti za obrazovanje odraslih, stvorilo dobro uređeno tržište obrazovnih programa i usluga u kome institucije nude programe obrazovanja i obuke pod jednakim uslovima i usvojenim standardima, te kako bi se zadovoljile potrebe tržišta rada i pojedinaca za znanjima i veštinama. Osim toga u Strategiji 
je istaknuta i potreba da se u skladu sa predviđenim standardima $\mathrm{i}$ istim uslovima omogući realizacija programa obrazovanja i obuke za odrasle i to od strane: škola za osnovno obrazovanje odraslih i redovnih osnovnih škola koje ispunjavaju uslove za rad sa odraslima; srednjih stručnih škola, odnosno njihovih centara za kontinuirano obrazovanje, odnosno obrazovanje odraslih; visokoškolskih institucija, odnosno njihove posebne organizacione jedinice - centra za usavršavanje i kontinuirano obrazovanje; narodnih, radničkih i otvorenih univerziteta; privrednih društava i njihovih asocijacija; udruženja; institucija za kulturu; privatnih organizacija za obrazovanje i obuku te stručnih udruženja.

Naglašavajući i opisujući karakteristike institucija/organizacija za obrazovanje odraslih, Strategija ustvari insistira na organizacionoinstitucionalnoj mreži kao na značajnom razvojnom elementu.

\section{Kadrovi za obrazovanje odraslih kao razvojni element strategije obrazovanja Odraslih}

Strategija obrazovanja odraslih Republike Crne Gore predviđa da se za srednjoročni period pripreme predlozi za osposobljavanje i školovanje kadra u oblasti obrazovanja odraslih koji bi mogli da obuhvate i osnivanje više škole za obrazovanja profesionalaca u oblasti andragogije, obrazovanje andragoga na Filozofskom fakultetu u Nikšiću, te osnivanje istraživačkog centra sa zadatkom unapređivanja učenja i poučavanja.

Strategija obrazovanja odraslih Republike Hrvatske se u posebnom članu 4.6 (Nastavnici u obrazovanju odraslih) bavi problematikom ovog razvojnog elementa (videti u: Strategija obrazovanja odraslih, 2004:22). Problemi su vidljivi u nedostatku pokazatelja koji bi precizno govorili o broju i strukturi nastavnika u obrazovanju odraslih. Ističe se potreba da nastavni kadar koji radi u programima formalnog obrazovanja, a nema nastavničko obrazovanje mora steći dodatno pedagoško-psihološko obrazovanje za rad u nastavi. Postavlja se pitanje zašto je izostavljeno dodatno andragoško obrazovanje, jer je reč o realizaciji programa za odrasle? Postoji mogućnost da se problem nalazi u podzakonskim aktima kojima nije uređeno posebno područje obrazovanja odraslih kada je u pitanju stručna sprema nastavnika, odnosno njihovo usavršavanje. Da bi se otklonili ovi problemi u Strategiji se preporučuje da Andragoški centar razvije modularne programe za osposobljavanje i usavršavanje nastavnog kadra koji radi u obrazovanju odraslih uključujući i programe e-Learning. Pored toga istaknuta je i potreba ponovnog organizovanja studija andragogije na fakultetima, jer Katedra andragogije na Univerzitetu u Rijeci ne može u 
potpunosti odgovoriti na potrebe osposobljavanja andragoškog kadra, jer poučavanje kao profesiju čeka odlučujuća promena u narednim desetljećima, gdje će nastavnici i vaspitači sve više postajati voditelji, mentori i posrednici u obrazovanju i učenju.

Kako bi se ostvario strateški cilj 3. „Poboljšanje kvaliteta i efikasnosti obrazovanja i obuke odraslih", Strategija Republike Makedonije ističe važnost obezbjeđenja visokokvalitetne nastave za odrasle. Da bi se to ostvarilo potrebno je inicirati i uspostaviti usavršavanje kadrova koji rade u obrazovanju odraslih. Ovim zadatkom je predviđeno da se pripremanjem kadrova za rad u obrazovanju odraslih, pored ostalih, posebno bave Institut za pedagogiju i Biro za razvoj obrazovanja koji se pretežno i bave obukom nastavnika i direktora. U Članu 6.9. Strategije posebno se govori o personalu u obrazovanju odraslih i tom prilikom ističe problem nepostojanja relevantnih statističkih podataka, kako bi se utvrdilo stvarno stanje kadrova koji rade u obrazovanju odraslih, odnosno njihove potrebe za osposobljavanjem i usavršavanjem. Strategija predviđa da je nužno za ovu kadrovsku strukturu razviti i ponuditi kontinuirane, fleksibilne i modularne programe za obrazovanje iz oblasti Andragogije, kako bi se što stručnije obavljali pojedinačni zadaci, ali time doprinijelo i razvoju same institucije.

Nastavnom kadru kao razvojnom elementu u Strategiji Republike Srbije se ne daje posebna pažnja. Ovim problemom Strategija se bavi samo kada je u pitanju zadatak utvrđivanja standarda obrazovanja i obuke s ciljem unapređenja kapaciteta i kvaliteta obrazovanja i obuke odraslih. Strategija predviđa uspostavljanje institucionalno-organizacionih standarda, a uz njih i standarda za nastavnike (edukatore odraslih), ali se detaljnije ne bavi problematikom nastavnika za odrasle. Međutim, Strategija R Srbije ne obraća posebnu pažnju na ukupan kadrovski potencijal (osim delimično u domenu edukatora odraslih), jer je profesionalizacija obrazovanja odraslih čvrsto utemeljena na univerzitetskom pripremanju andragoških kadrova i na njihovom kontinuiranom usavršavanju, što predstavlja svojevrstan „kapital” koji podupire ostale razvojne elemente i Strategiju u celini i stoga se smatra razvojnim faktorom iako se posebno eksplicitno ne naglašava kroz Strategiju.

\section{Finansiranje kao razvojni element strategije obrazovanja odraslih}

Sadašnje finansiranje obrazovanja odraslih u Republici Crnoj Gori je na neodgovarajućem nivou i neće moći omogućiti realizaciju same Strategije, pa je stoga potrebno obezbediti povećanje ukupnih investicija u ovu oblast. Strategija obrazovanja odraslih Republike Crne Gore se najdetaljnije bavi 
ovom problematikom i to u Članu 8. Strategije. U cilju uspostavljanja održivog sistema finansiranja procesa obrazovanja i učenja odraslih u Crnoj Gori, u početnom periodu Strategija predviđa razmatranje mogućnosti za realokaciju raspoloživih sredstava, a u kasnijoj fazi formiranje fondova za obuku, mogućnosti za smanjenje poreskih obaveza poslodavcima i pojedincima koji ulažu u proces obrazovanja i učenja odraslih, usmeravanje nadoknada po osnovu privremene nezaposlenosti i otpremnina za tehnološke viškove $\mathrm{u}$ proces realizacije programa obuke, uvođenje povoljnih kredita i vaučera za obrazovanje, itd. (videti u: Strategija obrazovanja odraslih Crne Gore, 2006:29). Prioritet u finasiranju treba da imaju programi i aktivnosti za oblasti koje predstavljaju komparativnu prednost Crne Gore za ukupni privredni i društveni razvoj. O ovom fundamentalnom pitanju, kako je navedeno u Strategiji, potrebno je obezbediti podršku postojećih ili potencijalnih međunarodnih investitora, uključujući Evropsku banku i MMF.

Finansiranjem kao razvojnim elementom, Strategija obrazovanja odraslih Republike Hrvatske se bavi u posebnom članu (4.3.), gde sublimira stanje i probleme vezane za finansiranje obrazovanja odraslih. Najveći problemi su vidljivi u nedostatku javne odgovornosti, nedostatku podrške države i lokalne samouprave obrazovanju odraslih. Kao jedan od krucijalnih problema navodi se fiskalna politika koja prema Zakonu o porezu na dodanu vrednost (PDV) sve ustanove za obrazovanje odraslih svrstava u red poreznih obveznika zajedno sa trgovačkim društvima, čime obrazovanje odraslih podliježe stopi poreza od $22 \%$. Takva politika zasigurno ne daje podsticaj obrazovanju odraslih, a i u suprotnosti je sa praksom većine razvijenih evropskih zemalja. Dodatna otežavajuća okolnost je i porez na dobit, koji je također obaveza ustanova za obrazovanje odraslih. Ovi problemi sigurno ne stimulišu i ne motivišu građane na obrazovanje, te je u Strategiji jasno istaknuto da bi Republika Hrvatska morala da sledi praksu evropskih zemalja s obzirom na nisku obrazovnu strukturu i visoke razvojne potrebe, te bi trebala osigurati održiv sistem finansiranja obrazovanja odraslih. U Strategiji nije dat primer kako bi taj sistem finansiranja mogao da izgleda.

Iako se Strategija obrazovanja odraslih Republike Makedonije finansiranjem kao razvojnim elementom bavi u dva člana Strategije (6.4. - Finansiranje obrazovanja odraslih i 6.11. - Finansije i adekvatni resursi), u Strategiji nisu vidljiva rešenja za postojeće dosta teško stanje u oblasti finansiranja ove delatnosti. U članovima su navedeni principi finansiranja obrazovanja odraslih, ali bez jasnih koraka kako da se prevaziđe trenutna situacija. U skladu sa Zakonom o obrazovanju odraslih u Strategiji se navodi 
da se sredstva za finansiranje obrazovanja odraslih obezbeđuju iz budžeta Republike Makedonije, jedinica lokalne samouprave te od pojedinaca odnosno učesnika u samom obrazovanju.

Strategija obrazovanja odraslih Republike Srbije daje jasne smernice kada je u pitanju finansiranje obrazovanja odraslih kako bi se ostvario četvrti cilj Strategije „Unapređenje kapaciteta i kvaliteta obrazovanja i obuke odraslih”. Trenutno finansiranje obrazovanja odraslih u Republici Srbiji se obezbeđuje kroz javne budžete, od strane privrednih društava i privatnih poslodavaca, pojedinaca i udruženja te kroz međunarodne organizacije i programe. U članu 4.2. same Strategije dato je jasno uputstvo šta je potrebno uraditi u oblasti finansiranja obrazovanja odraslih, gde je istaknuta potreba da se izvrši realokacija budžetskih sredstava, te da se jedan deo usmeri na finansiranje obrazovanja odraslih. Mogućnosti za realokaciju sredstava se vide u smanjenju školske populacije i broja škola u zemlji, što bi moglo da predstavlja značajan izvor za finansiranje obrazovanja odraslih. Pored toga potrebno je izvršiti zaokret od pasivne ka aktivnoj politici zapošljavanja, kako bi se dio sredstava preusmerio u obuke nezaposlenih i potencijalno nezaposlenih. Strategija predviđa i stimulaciju poreske strategije prema poslodavcima i pojedincima koji ulažu o obrazovanje odraslih, te formiranje fondova za obuku uz uvođenje povoljnih kredita za sticanje inicijalnih kvalifikacija ili prekvalifikacija. Osim toga predloženo je i uspostavljanje sistema akreditacije institucija i programa, kako bi se stimulisali pojedinci i privredna društva da ulažu u obrazovanje i obuku, te da se povećaju investicije u obuku nezaposlenih lica, koji bi participirali u nacionalno akreditovanim programima na nivou lokalnih zajednica i privrednih društava.

\section{Zaključna razmatranja}

Analizirajući četiri nacionalne strategije obrazovanja odraslih u regionu Jugoistočne Evrope možemo zaključiti da su svi razvojni elementi (koje smo na osnovu izveštaja, deklaracija i rezolucija međunarodnih konferencija o obrazovanju odraslih i rasprava o razvojnosti obrazovanja izdvojili kao ključne) zastupljeni u analiziranim strategijama. Zastupljenost je merena trostepenom skalom procene, pri čemu je osnovu procene činio kritički sud istraživača prilikom analize strategija. Zakon o obrazovanju odraslih $\mathrm{i}$ finansiranje obrazovanja odraslih kao razvojni elementi uglavnom spadaju u kategoriju „veoma naglašenih razvojnih elemenata”, dok se kadrovi za obrazovanje odraslih tretiraju kao razvojni element koji je slabije naglašen (sa prosekom 1,75) u analiziranim strategijama obrazovanja odraslih. (Tabela.2). 
Tabela 2.: Razvojni elementi sadržani u strategijama obrazovanja odraslih (1-slabo naglašen; 2-naglašen; 3-vrlo naglašen.)

\begin{tabular}{|l|c|c|c|c|c|}
\hline Država & $\begin{array}{l}\text { Zakon o } \\
\text { obrazovanju } \\
\text { odraslih }\end{array}$ & $\begin{array}{l}\text { Institucije/provajderi } \\
\text { - realizatori } \\
\text { obrazovanja odraslih }\end{array}$ & $\begin{array}{l}\text { Kadrovi za } \\
\text { obrazovanje } \\
\text { odraslih }\end{array}$ & Finansiranje & $\begin{array}{l}\text { Srednja } \\
\text { vrednost }\end{array}$ \\
\hline $\begin{array}{l}\text { Republika } \\
\text { Crna Gora }\end{array}$ & 3 & 3 & 2 & 3 & 2.75 \\
\hline $\begin{array}{l}\text { Republika } \\
\text { Hrvatska }\end{array}$ & $\mathbf{3}$ & $\mathbf{1}$ & $\mathbf{2}$ & $\mathbf{3}$ & $\mathbf{2 . 2 5}$ \\
\hline $\begin{array}{l}\text { Republika } \\
\text { Makedonija }\end{array}$ & $\mathbf{3}$ & $\mathbf{3}$ & $\mathbf{2}$ & $\mathbf{2}$ & $\mathbf{2 . 5 0}$ \\
\hline $\begin{array}{l}\text { Republika } \\
\text { Srbija }\end{array}$ & $\mathbf{2}$ & $\mathbf{3}$ & $\mathbf{1}$ & $\mathbf{3}$ & $\mathbf{2 . 2 5}$ \\
\hline $\begin{array}{l}\text { Srednja } \\
\text { vrijednost }\end{array}$ & $\mathbf{2 . 7 5}$ & $\mathbf{2 . 5 0}$ & $\mathbf{1 , 7 5}$ & $\mathbf{2 . 7 5}$ & \\
\hline
\end{tabular}

Zakon i finansiranje su već po definiciji (bez obzira na oblast za koju se vežu) značajni, ,jaki” razvojni elementi te stoga ohrabruje podatak da su identifikovani kao takvi u svim analiziranim strategijama. Značajno su naglašeni i organizaciono institucionalni resursi, što je za očekivati ako se ima u vidu da oni predstavljaju objektivizaciju sistema obrazovanja odraslih putem kojeg se ostvaruju obrazovni, ali i strateški ciljevi. Međutim, iznenađenje je da su kadrovi za obrazovanje odraslih kao razvojni element nedovoljno naglašeni u strategijama, iako su brojna istarživanja potvrdila da je kadrovski potencijal inicijator pozitivnih promena i nosilac razvoja. Objašnjenje ovog „,iznenađenja” nalazimo u činjenici da je proces profesionalizacije andragoških kadrova odavno počeo u Srbiji te da Strategija obrazovanja odraslih u Srbiji i nije imala potrebu naglašavanja tog razvojnog elementa (što je uticalo da ovaj razvojni element ima najnižu prosečnu vrednost).

Zanimljivo je da su razvojni elementi više prisutni u strategijama Crne Gore i Makedonije, a manje u strategijama Hrvatske i Srbije. Da li to znači da je razvoj delatnosti obrazovanja odraslih na zadovoljavajućem (ili optimalnom) nivou u zemljama čije strategije manje naglašavaju razvojne elemente, ili su pak strategije Crne Gore i Makedonije ambicioznije u pogledu razvoja obrazovanja odraslih? Moguće je DA u oba slučaja, ali je odgovore ipak najbolje potražiti nakon realizacije strategija. 
Ovom prilikom prezentirani nalazi su u skladu sa nalazima ranijih komparativnih analiza sistema obrazovanja odraslih u Jugoistočnoj Evropi, gdje se došlo do rezultata da su upravo Zakon i finansiranje obrazovanja odraslih detektovani kao problemi u razvoju sistema obrazovanja odraslih, pa se u skladu sa tim i kroz kasnije usvojene strategije najviše težilo ka rešavanju upravo tih pitanja, odnosno pitanja pravnog regulisanja i finansiranja, da bi se sistemi obrazovanja odraslih u budućnosti mogli organizovati na način da budu dorasli izazovu sve zahtevnije okoline (vidi Alibabić, 2002: 125). Međutim i pored usvojenih strategija u zemljama Jugoistočne Evrope koje su i bile predmet naše analize, još uvek su vidljivi problemi u implementaciji samih strateških akata i praktičnoj primeni te njihov transfer u akcioni plan. Ključnu ulogu ovde može da odigra dijalog sa političkim, odnosno zakonodavnim strukturama i to baš u fazi akcionih planova, kako bi se uspela osigurati politička i finansijska podrška, ali i podela odgovornosti (vidi Popović 2010: 20).

Umjesno je na kraju istaći da su zakon, finansiranje, institucije, kadrovi - kao razvojni elementi, posmatrani pojedinačno - izolovano, iako njihova razvojna snaga dolazi do izražaja tek u njihovom združenom delovanju. U tom kontekstu, a na osnovu rezultata naše analize, može se zaključiti da svaka analizirana strategija odražava snažan razvojni potencijal izražen kroz združeno delovanje razvojnih elemenata.

\section{DEVELOPMENTAL ELEMENTS IN STRATEGIES OF ADULT EDUCATION}

\section{- Abstract -}

One of the basic and dominant ways of realising life-long educational and learning is educating adults. Success of this process requires adequate environment, so the task of each government and social partners is ensuring environment supporting permanent and continuous acquiring new knowledge and skills. Education of adults is the area which has been neglected in the countries of South - Eastern Europe due to many transitional problems, first of all economic ones. Although it has been becoming more and more important issue of the educational policies in the region, adult education has not become the priority yet. Some countries of the South - Eastern Europe have adopted strategies of adult education and some principles of adult 
education, but their adoption does not mean implementation, i.e. the "wheel" which will start development of adult education and realisation of the educational aims. Considering the fact that the aim of the state policy of adult education is obtaining planned development of the area - planned building of the social surrounding and relevant mechanism and resources for education and learning of the adults, i.e. Creating the system for realising the mission of the for achieving the vision of the adult education, and it is necessary that these strategies an instrument of educational policy contain the key developmental elements. So, the intention of this paper is to see and determine the key developmental elements in the adopted strategies based on the critical analyses of the four strategies of the regional countries. The overall presence was measured bay the scale of estimation, and the basis of the estimation was the critical opinion of the researches during strategies analysis. The analysis resulted with the conclusion that the law of adult education and financing education of the adults as a developmental element belong of the category of "very stressed developmental elements" and the stuff for adult education are treated as developmental element which is inadequately stressed (the average is 1.75) in the analysed strategies.

Law, financing, institutions, and stuff as developmental elements have been observed in our research individually - isolated as their developmental strength which comes into full force in their mutual work. In this context, based on the analysis results, it can be concluded that each analysed strategy represents a strong developmental potential stressed through mutual work of developmental elements.

\section{Key words: life - long education and learning, adult education, strategies of adult education, developmental elements of the strategy, educational policy.}

\section{Literatura:}

- $\quad$ Alibabić, Š., (2002) Teorija organizacije obrazovanja odraslih, Institut za pedagogiju i andragogiju Filozofskog fakulteta, Beograd.

- Alibabić, Š., (2011), Konceptualne i organizacione karakteristike daljeg obrazovanja, Obrazovanje odraslih, Br.2, Vol.XI, BKC Sarajevo i DVV international u BiH, Sarajevo, str.83-97.

- Alibabić, Š., Milićević, V., Drakulić, M., (2011) Modeli učenja u korporacijama, Andragoške studije, br.2, IPA Filozofskog fakulteta, Beograd, str.65-83. 
- Bečić E. i dr., (2009) Međunarodne organizacije o obrazovanju odraslih 1. dio, Agencija za obrazovanje odraslih, Zagreb.

- Boud, D., Garrick, J., (1999) Understanding Learning at Work, Routledge, London.

- Knoll J.H. (2011) „Lifelong Learning” - A New Term for an Old Idea? The Search for Historical Roots, Andragoške studije, br. 1, IPA Filozofskog fakulteta, Beograd, str.7-21.

- DVV international Regional Office for South East Europe, (2008) Nacionalni izvještaj o razvoju i stanju obrazovanja i učenja odraslih Bosna i Hercegovina, Sarajevo.

- Ministarstvo obrazovanja i nauke Republike Makedonije, (2006) Nacionalna strategija obrazovanja u Republici Makedoniji 2005-2015, Skoplje.

- Časopis za obrazovanje odraslih i kulturu - Obrazovanje odraslih, (2006) Vol. VI, br. 2, Sarajevo.

- Popović K., (2010) Obrazovanje odraslih u Jugoistočnoj Europi, Obrazovanje odraslih, Vol. X, br. 1, Sarajevo.

- Savićević, D., (2000) Put ka društvu učenja, DP Đuro Salaj i JNIP Prosvetni pregled, Beograd.

- Vlada Republike Hrvatske, (2004) Strategija obrazovanja odraslih, Zagreb.

- Vlada Republike Crne Gore, (2006) Strategija obrazovanja odraslih Crne Gore 2005.-2015., Podgorica.

- Vlada Republike Srbije, (2006) Strategija razvoja obrazovanja odraslih u Republici Srbiji, Vršac.

- Vlada Republike Makedonije, (2010) Strategija za obrazovanje odraslih, Skoplje.

- Vijeće ministara Bosne i Hercegovine, (2007) Strategija razvoja stručnog obrazovanja i obuke u Bosni i Hercegovini za period 2007.-2013. godine, Sarajevo.

- Vijeće ministara Bosne i Hercegovine, (2008) Strateški pravci razvoja obrazovanja u Bosni i Hercegovini sa planom implementiranja 2008.2015., Sarajevo. 